\title{
PENGARUH PEMBELAJARAN PENDIDIKAN AGAMA KATOLIK TERHADAP PERKEMBANGAN IMAN DAN PERUBAHAN PERILAKU SISWA SEKOLAH MENENGAH PERTAMA KATOLIK DI KOTA MADIUN
}

\author{
Oleh: \\ Dicky Melyawanto, Ola Rongan Wilhemus $\left.{ }^{*}\right)$ \\ STKIP Widya Yuwana \\ *) penulis korespondensi, olarongan@widyayuwana.ac.id
}

\begin{abstract}
The task of organizing education is primarily the responsibility of parents and assisted by the community as long as it is needed. The task of organizing education is also the responsibility of the Church. The Church takes part in the world of education, among others, through Catholic religious education in Catholic schools. The learning process of Catholic Religious Education is intended to improve the faith of Catholic youth. The research was conducted by using qualitative research method. Qualitative research method is a form of research designed to examine attitudes, views, feelings, and behavior of individuals or groups of people or social issues being investigated. This study aims to analyze the extent to which Catholic Religious Education affects the development of faith and behavioral change of the Catholic Junior High School students in Madiun. The results of the research indicated that 7 (58\%) of respondents stated that junior high school students were students between 13-15 years old. There were 12 (100\%) respondents said that Catholic Religious Education taught in the School was able to help the junior high school students to have more knowledge about Jesus and his preaching. As many as 6 (50\%) of respondents stated that Catholic Religious Education is very helpful to get know more about themselves personally. There were 8 (67\%) of respondents stated that the teaching of Catholic Religion made their faith progressively improved. Broadly speaking, all respondents experienced that Catholic Religious teaching has made their Catholic faith being developed so far. It made the respondents more diligent and actively involved in throughout Catholic Church activities and any social affairs.
\end{abstract}

Keywords: Catholic studies, faith, behavior 


\section{PENDAHULUAN}

Kaum beriman Kristiani yang telah dibaptis dipanggil untuk menjalani hidup yang selaras dengan ajaran Injili, berhak atas pendidikan Kristiani, serta mendapatkan pembinaan sewajarnya untuk mencapai kedewasaan pribadi manusiawi serta mengenal dan menghayati misteri keselamatan (bdk. KHK Kan. 217). Supaya dapat hidup selaras dengan ajaran Injili, maka pendidikan menjadi hal yang sangat penting, terutama Pendidikan Agama Katolik. Pendidikan Kristen perlu diusahakan supaya dapat terselenggara secara baik. Penyelenggaran pendidikan ini harus mencakup seluruh umat Kristen, termasuk di dalamnya juga para remaja. Dengan demikian, anak-anak dari keluarga Kristiani ini diharapkan mampu hidup sesuai dengan iman dan Ajaran Gereja.

Upaya Gereja dalam menyelenggarakan pendidikan terlihat jelas dengan kehadiran sekolah-sekolah Katolik. Penyelenggaraan pendidikan pada sekolah Katolik dijiwai oleh semangat Injil, kebebasan dan cinta kasih. Dengan semangat Injili ini sekolah-sekolah Katolik membantu remaja mengembangkan diri serta pengetahuan tentang dunia, kehidupan dan manusia yang senantiasa diterangi oleh terang iman (bdk. GE Art. 8). Gereja menyalurkan warisan iman Gereja kepada kaum muda termasuk para remaja lewat sekolah-sekolah Katolik ini. Gereja hadir melalui proses pembelajaran yang berlangsung, terutama melalui Pendidikan Agama Katolik. Salah satunya, Gereja hadir dalam kehidupan dan dinamika pendidikan di SMP. Usia anak-anak yang sekolah pada jenjang pendidikan ini ialah antara 13-15 tahun. Dalam rentang usia seperti inilah seorang anak memiliki permasalahan yang serius, dan salah satu masalah serius itu adalah krisis identitas. Krisis identitas inilah yang mendorong para remaja berusaha mencari dan menemukan identitas pribadinya.

Penelitian ini dibuat untuk menjawabi beberapa pertanyaan penting tentang pengaruh dinamika pembelajaran Agama Katolik di sekolah, yaitu: Siapa itu siswa-siswi SMP dan bagaimana dinamika perkembangan hidup sosial dan kognitif mereka? Bagaimana proses pembelajaran PAK yang berlangsung di SMP Katolik di Kota Madiun? Materi pengajaran apa saja yang diajarkan bagi siswasiswi SMP? Sejauh mana pembelajaran PAK berpengaruh pada perkembangan iman dan perilaku siswa di SMP Katolik di Kota Madiun?

Berdasarkan pertanyaan-pertanyaan di atas, maka tulisan ini ditulis dengan tujuan sebagai berikut: 1) Mendefinisikan siapa itu siswa-siswi SMP dan bagaimana perkembangan dan perubahan perilaku mereka; 2) Mendeskripsikan materi pengajaran Pendidikan Agama Katolik yang diajarkan kepada para siswasiswi SMP; 3) Menjelaskan bagaimana proses pengajaran Pendidikan Agama Katolik yang dilakukan dalam kelas bagi siswa-siswi SMP; 4) Menganalisis sejauh mana pengajaran Pendidikan Agama Katolik di kelas berpengaruh terhadap 
perkembangan penghayatan iman siswa-siswi SMP di sekolah, keluarga dan masyarakat.

\section{DAMPAK PEMBELAJARAN AGAMA KATOLIK DI SMP}

Belajar mengandung arti "berusaha untuk memperoleh kepandaian atau ilmu”. Sedang kata pembelajaran diartikan sebagai sebuah proses, cara atau perbuatan menjadikan seseorang atau makhluk hidup belajar. Pembelajaran merupakan sebuah proses atau cara yang dilakukan untuk memperoleh ilmu (Depdiknas, 2008:23). Proses belajar terjadi antara lain mencakup pengaturan stimulus yang diterima dan menyesuaikannya dengan struktur kognitif yang sudah dimiliki dan terbentuk dalam pikiran seseorang berdasarkan pemahaman dan pengalaman-pengalaman sebelumnya (Budiningsih, 2005:34). Proses belajar mencakup penyesuaian antara hal yang sedang dipelajari dengan apa yang sudah didapat oleh seseorang dari pengalaman hidupnya.

Agama memiliki peran yang amat penting dalam kehidupan manusia. Agama menjadi pemandu dalam upaya mewujudkan suatu kehidupan yang bermakna, damai dan bermartabat. Pendidikan agama dimaksudkan untuk membentuk siswa menjadi pribadi yang beriman dan bertaqwa kepada Tuhan Yang maha Esa dan berakhlak mulia, dan demi peningkatan potensi spiritual (Komkat KWI, 2007:9). Untuk mewujudkan tujuan tersebut, maka materi Pendidikan Agama Katolik mencakup empat tema pokok, yaitu: pribadi siswa, Yesus Kristus, Gereja, dan Kemasyarakatan

Topik-topik di awal pembelajaran Pendidikan Agama Katolik SMP berfokus pada upaya membantu siswa menemukan kesadaran dan kepercayaan diri sebagai pribadi ciptaan Allah, baik sebagai laki-laki maupun perempuan yang bermartabat luhur dan memiliki kelebihan dan sekaligus keterbatasan. Dengan kesadaran tersebut siswa akan termotivasi untuk mampu menerima diri apa adanya, mensyukurinya, sekaligus mengarahkan pengembangan dirinya secara lebih baik (Komkat KWI, 2004:14 (Buku Guru 1). Salah satu kebutuhan remaja dalam mengembangkan dirinya adalah seorang pribadi yang dapat menjadi figur, model, sekaligus teladan hidupnya. Pendidikan Agama Katolik mengarahakan para siswa untuk menjadikan Yesus Kristus sebagai model dan teladan hidup yang sempurna bagi para siswa. Oleh karena itu, Pendidikan Agama Katolik mengajak para siswa mendalami hidup, karya, dan kepribadian Yesus untuk dijadikan model sekaligus arah pengembangan diri para siswa (Komkat KWI, 2004:155 (Buku Guru 1)).

Karya Yesus berpuncak pada peristiwa sengsara, wafat dan kebangkitan Yesus Kristus. Dari peristiwa sengsara, wafat, dan kebangkitan Yesus Kristus, para siswa diajak untuk mendalami bahwa perwujudan jati diri di tengah kehidupan sosial seringkali mengalami benturan. Tidak hanya benturan, resiko 
nyawa pun siap menantang, sebagaimana dialami oleh Yesus Kristus yang menderita sampai wafat di salib. Keagungan jati diri Yesus tampak pula dalam keinginan-Nya membangun kelompok, kebersamaan, dan persekutuan. Yesus mengajak para murid-Nya untuk terlibat dalam karya pewartaan Kerajaan Allah, menjalankan perutusan Bapa (Komkat KWI, 2004:13 (Buku Guru 2)).

Karya Yesus membangun persekutuan para murid tidaklah sia-sia. Kehadiran Yesus melalui Roh Kudus dalam persekutuan menjadi sumber kekuatan yang luar biasa. Berkat kehadiran-Nya, persekutuan yang dibangun Yesus berkembang pesat, semakin luas, serta menyebar dan hadir ke seluruh pelosok dunia. Persekutuan itu mempunyai wujud baru yang beragam, namun tidak lepas dari model awal yang dibangun Yesus. Gereja Kristus semakin memperlihatkan kekiniannya yang tampak dari keanggotaan dan pelayanannya. Gereja terus berjuang mewujudkan diri sebagai tanda dan sarana (sakramen) keselamatan Allah bagi manusia. Para siswa dikenalkan dan diajak untuk mendalami sakramen Gereja sebagai tanda dan sarana keselamatan bagi manusia. Perkembangan, keanggotaan dan pelayanan Gereja ini dapat menjadi referensi dan bahan refleksi bagi para siswa supaya mampu menempatkan dan melibatkan diri dalam karya pelayanan Gereja sesuai dengan kemampuan yang mereka miliki (bdk. Komkat KWI, 2004:111,133 (Buku Guru 2)).

Selain sebagai anggota Gereja, setiap orang Kristiani juga menjadi anggota masyarakat. Yesus dan Gereja menuntut supaya setiap anggota Gereja sungguh terlibat dalam kehidupan bermasyarakat. Suka-duka masyarakat menjadi sukaduka anggota Gereja (bdk. Gaudium et Spes. Art. 1). Persoalan masyarakat menjadi persoalan Gereja juga. Oleh karena itu setiap anggota Gereja perlu sungguh-sungguh sadar bahwa ia adalah warga masyarakat yang penuh. Setiap orang harus bisa menerima dan menghayati aturan main kehidupan bermasyarakat, tahu hak dan kewajiban sebagai anggota masyarakat (bdk. Komkat KWI, 2004:79-80 (Buku Guru 3).

\subsection{Perkembangan Iman Remaja}

Iman adalah ikatan pribadi manusia dengan Allah dan sekaligus tidak terpisahkan dari itu, persetujuan secara bebas terhadap segala kebenaran yang diwahyukan Allah. Sebagai ikatan pribadi dengan Allah dan persetujuan terhadap kebenaran yang diwahyukan Allah, iman Kristen berbeda dengan kepercayaan yang diberikan kepada seorang manusia. Menyerahkan diri seluruhnya kepada Allah, dan mengimani secara absolut apa yang Ia katakan adalah tepat dan benar. Sebaliknya adalah sia-sia dan salah memberikan kepercayaan yang demikian itu kepadaseorang makhluk (KGK art. 150).Iman merupakan suatu hal yang tidak bisa dilihat secara kasat mata. Namun, iman dapat dilihat dari sikap batiniah yang dimunculkan dalam perilaku keseharian seseorang terutama yang berhubungan 
dengan hal peribadatan. Iman menuntut persetujuan yang bebas dan bukan karena keterpaksaan. Siswa yang beriman berarti memiliki kepercayaan dan keyakinan kepada Allah.

Masa remaja, seringkali dihubungkan dengan mitos dan stereotip mengenai penyimpangan dan ketidakwajaran perilaku hidup. Hal ini dapat dilihat dari berbagai teori psikologi perkembangan yang membahas tentang gangguan emosi dan penyimpangan perilaku remaja akibat tekanan-tekanan yang dialaminya sebagai akibat dari perubahan fisik dan mental yang terjadi pada dirinya dan juga sebagai akibat dari proses penyesuaian diri dengan lingkungan hidup dan pergaulan baru dengan orang dewasa (Supriyadi, 2012:28).

Remaja merupakan sebuah tahapan hidup manusia yang bersifat peralihan dan tidak menetap. Hal ini menyebabkan remaja pada umumnya rawan terhadap berbagai pengaruh negatif, seperti narkoba, kriminal, seks bebas, dsb. Di sisi lain, masa remaja merupakan masa yang sangat baik untuk pengembangan potensi positif remaja. Masa remaja juga merupakan masa pencarian nilai-nilai hidup. Oleh arena itu, bimbingan agama menjadi penting untuk pegangan hidup remaja (Tse, 2011:37).

Perkembangan spiritualitas merupakan hal yang sangat penting bagi manusia, termasuk remaja. Perkembangan spiritualitas menjadi acuan untuk mempelajari perkembangan hidup spiritual manusia. Salah satu teori tersebut yaitu teori perkembangan spiritual menurut Fowler. Teori ini mengungkapkan beberapa hal sebagai berikut: Pertama, Primal Faith terjadi pada rentang usia 0-2 tahun. Perkembangan ini ditandai dengan rasa percaya dan setia anak pada pengasuhnya. Kepercayaan ini tumbuh atas dasar relasi yang baik antara anak dan pengasuhnya. Kedua, Intuitive-Projective Faith, terjadi dalam rentang usia 2-7 tahun. Perkembangan spiritual anak bersifat peniruan. Perkembangan spiritual ini merupakan hasil penggabungan dari hasil pengajaran dan contoh-contoh dari orang dewasa. Ketiga, Mythical-Literal Faith terjadi dalam rentang usia 7-11 tahun. Selaras dengan perkembangan kognitif, anak mulai memaknai tradisi masyarakat. Tuhan digambarkan sebagai seorang pribadi, orang tua, penguasa. Keempat, Synthetic-Conventional Faith terjadi dalam rentang usia 12-21 tahun. Tahap ini ditandai dengan kesadaran remaja tentang simbolisme dan memiliki lebih dari satu cara untuk mencari kebenaran. Sistem kepercayaan remaja pada tahap ini mencerminkan pola kepercayaan masyarakat pada umumnya. Di sisi lain, kesadaran kritisnya menjadikan remaja berani dan mampu melakukan kritik atas ajaran-ajaran yang diberikan lembaga keagamaan kepadanya. Pada tahap ini remaja juga mulai mencapai pengalaman bersatu dengan Tuhan. (Desmita, 2012:278-280). 


\subsection{Perilaku dan Perkembangan Perilaku Siswa SMP}

Perilaku, secara umum diartikan sebagai pola atau tindakan hidup yang terwujud dalam hidup keseharian. Perilaku ini dipengaruhi oleh pembiasaan yang diberlakukan kepada seseorang setiap harinya. Kebiasaan yang berulang-ulang dijalani inilah yang membentuk perilaku yang sulit untuk diubah. Untuk itulah diperlukan pembinaan yang intensif kepada seorang pribadi, terutama remaja, supaya memiliki perilaku yang positif.

Masa remaja merupakan masa yang efektif bagi perkembangan psikologi, fisik, kognitif, sosial dan spiritual. Oswal Kroch, memandang ciri-ciri psikologis terdapat pada anak-anak pada umumnya adalah pengalaman keguncangan jiwa yang ditunjukkan dalam bentuk sifat "trotz" atau sifat "keras kepala”. Oswal Kroch membagi periodesasi perkembangan anak menjadi tiga fase. Pertama, fase anak awal; kedua, fase keserasian sekolah, dan ketiga, fase kematangan. Namun untuk kepentingan penelitian ini, hanya akan membahas tentang fase kematangan. Fase kematangan terjadi antara usia 13-21 tahun. Fase ini dimulai setelah berakhirnya gejala-gejala trotz kedua yang muncul dalam fase keserasian sekolah. Dalam fase ini remaja mulai menyadari kekurangan dan kelebihannya, dan menanggapinya dengan sikap yang wajar. Remaja mulai dapat menghargai pendapat orang lain, dapat memberikan toleransi terhadap keyakinan lain. Hal ini dikarenakan kesadaran atas kesamaan hak antara dirinya dengan orang lain. Masa ini merupakan masa bangkit atau terbentuknya kepribadian yang mantap (Desmita, 2012:24).

Kata "kognitif”, berkaitan dengan pola pikir seseorang. Pola pikir ialah alur pemikiran yang muncul dan ada dalam setiap individu karena mengalami suatu rangsangan tertentu. Pola pikir remaja telah berkembang lebih maju. Remaja sudah memiliki pola pikir sendiri untuk mengatasi permasalahan yang dihadapinya. Bahkan remaja dapat pula membayangkan dan mencari alternatif pemecahan untuk masalah yang dihadapinya. Hal inilah yang disebut pola pikir "multidimensi". Remaja tidak hanya memfokuskan diri pada pemecahan satu masalah saja, tetapi dapat memikirkan pemecahan terhadap beberapa masalah dalam satu waktu sekaligus. Kemampuan berpikir yang sudah berkembang ini membuat remaja tidak lagi menerima informasi apa adanya, tetapi mengolahnya sedemikian rupa sesuai dengan pemikiran mereka sendiri. Kemampuan berpikir ini juga digunakan untuk mengolah pengalaman masa lalu dan masa sekarang untuk masa yang akan datang. Dengan kata lain, pola pikir remaja yang berkembang ini sudah atau dapat melihat jauh ke depannya.

Selain mengalami perkembangan secara fisik, kognitif dan sosial, remaja juga mengalami perkembangan spiritual. Agama menjadi hal yang penting dan menjadi dasar pemikiran dan perkembangan moral hidup seorang remaja. Dinamika pergulatan yang dialami remaja tentu saja dialami oleh remaja Katolik. 
Pengalaman akan persimpangan jalan yang menyulitkan, status dan tanggungjawab sosial baru, konflik dan pertentangan nilai kehidupan serta pengalaman akan usaha mencari identitas diri sering kali membuat remaja Katolik harus berbenturan dengan kelompok senior dalam Gereja. Tentu saja benturan ini dapat membawa ketegangan tetapi juga harapan baru (Supriyadi, 2012:33-34). Bollinger, menggambarkan kebutuhan spiritual merupakan kebutuhan terdalam dalam dari diri seseorang. Apabila kebutuhan ini terpenuhi, maka seorang individu, dalam hal ini remaja, akan menemukan identitas dan makna hidup yang penuh arti (Desmita (2012: 265).

Perkembangan fisik pada masa remaja terjadi sangat pesat. Perkembangan fisik sangat terlihat karena masa remaja adalah masa di mana seseorang mengalami masa pubertas. Salah satu indikasi pertubuhan fisik seorang remaja adalah terjadinya perubahan bentuk tubuh atau fisik. Sebagai contoh, mulai tumbuhnya kumis dan janggut, jakun; bahu dan dada melebar; suara berat; tumbuh bulu di ketiak, di dada, di kaki, dan di lengan, dan di sekitar kemaluan; dan otot-otot menjadi kuat pada remaja laki-laki. Sedang pada perempuan terlihat dari membesarnya payudara dan pinggul, suara menjadi halus, tumbuh bulu di ketiak dan di sekitar kemaluan. Perubahan bentuk tubuh inilah yang akhirnya mempengaruhi perubahan penampilan remaja (Desmita, 2012:75-79).

Dalam dunia remaja, hubungan lebih banyak terjalin dengan teman sebaya. Hubungan remaja dengan teman sebaya merupakan hal yang sangat penting bagi perkembangan sosial remaja. Bersama teman sebaya, remaja belajar untuk saling melengkapi satu sama lain. Di sini remaja juga mulai belajar peduli dengan sesamanya. Remaja belajar tentang hubungan timbal balik yang simetris. Artinya hubungan sosial didasarkan pada sikap saling memberi dan menerima secara adil. Ketika menjalin hubungan dengan teman sebaya ini, remaja belajar untuk mempersiapkan diri membangun hubungan dengan masyarakat yang lebih luas (bdk. Desmita, 2009:219-220).

\subsection{Dampak Pembelajaran Pendidikan Agama Katolik Terhadap Iman dan Perubahan Perilaku Siswa SMP}

Perwujudan perilaku belajar biasanya lebih sering tampak dalam perubahan-perubahan yang terjadi dalam diri seseorang, salah satunya yaitu tingkah laku afektif. Tingkah laku afektif menyangkut keanekaragaman perasaan seperti: takut, marah, sedih, gembira, kecewa, senang, benci, was-was, dan sebagainya. Seorang siswa, misalnya, dianggap sukses dalam belajar agama apabila ia telah menyenangi dan menyadari dengan ikhlas kebenaran agama yang ia pelajari. Dengan kesadaran itu, siswa akan menjadikan kebenaran itu "sistem nilai diri” dan penuntun hidup (Syah, 2010: 116-120). 
Selain kesadaran akan kebenaran agama, dampak pembelajaran Pendidikan Agama Katolik harusnya juga tampak dari rasa memiliki (Sense of belonging) kepada Gereja. Sense of belonging dalam hidup menggereja perlu diwujudnyatakan melalui partisipasi aktif dalam bentuk perhatian, sumbangan pikiran dan pelayanan terhadap sesama. Partisipasi aktif ini merupakan gambaran pemahaman yang benar dan luas tentang kehidupan menggereja. Terutama pemahaman tentang usaha pewartaan karya keselamatan Allah melalui kata-kata, perbuatan serta kesaksian hidup merupakan tanggung jawab semua anggota Gereja. Setiap anggota Gereja mewujudnyatakan pewartaannya sesuai dengan kemampuannya masing-masing. Hal serupa juga ditekankan dalam Kitab Hukum Kanonik Kanon 204 - § 1. "Kaum beriman Kristiani ... dengan caranya sendiri mengambil bagian dalam tugas imami, kenabian dan rajawi Kristus, dan sesuai dengan kedudukan masing-masing,...”. Oleh karena itu tidak ada alasan lagi bagi setiap anggota Gereja untuk tidak terlibat dalam kehidupan menggereja (bdk. Supriyadi, 2012:34-35).

III. HASIL PENELITIAN : IDENTITAS, MATERI, PROSES, SERTA PENGARUH PENGAJARAN AGAMA KATOLIK TERHADAP PERKEMBANGAN DAN PENGHAYATAN IMAN SISWA SMP

\subsection{Identitas, Perkembangan dan Perubahan Perilaku Siswa-siswi SMP}

Hasil penelitian tentang siapa itu siswa-siswi SMP mengungkapkan bahwa, 7 (58 \%) responden menyatakan bahwa termasuk siswa-siswi SMP ialah siswa-siswi yang berusia antara 13-15 tahun. Enam (6) responden (50 \%) menyatakan bahwa siswa-siswi SMP ialah siswa-siswi yang telah tamat dari jenjang pendidikan SD dan sedang melanjutkan pendidikan pada jenjang pendidikan Sekolah Menengah Pertama. Siswa-siswi ini juga termasuk dalam usia remaja, sehingga cara berpikirnya pun lebih dewasa dari cara berpikir anak-anak Sekolah Dasar (SD). Analisis data tentang perkembangan aspek psikologi, fisik, kognitif, sosial, dan spiritual siswa-siswi SMP, menunjukkan bahwa 11 (92 \%) responden menyatakan bahwa secara psikologi, para siswa-siswi SMP cenderung lebih dewasa dan terbuka.

Masa remaja awal (12-15 tahun), individu mulai meninggalkan peran sebagai anak-anak dan berusaha mengembangkan diri sebagai individu yang unik dan tidak tergantung pada orang tua. Fokus dari tahap ini adalah penerimaan terhadap bentuk dan kondisi fisik serta adanya konformitas yang kuat dengan teman sebaya (Huda, 2013: 3).

Berkaitan dengan jati diri, individu yang berada dalam masa remaja akan berusaha "menjadi seseorang” atau berusaha menemukan identitas dirinya sebagai “AKU”. Jati diri ini penting bagi remaja untuk mendapatkan pengakuan dan tempat di lingkungan hidup dan pergaulannya. Lebih jauh lagi, indentitas diri ini 
akan sangat penting dan berpengaruh karena menentukan individu untuk menjadi “siapakah” atau “apakah” di masa yang akan datang (bdk. Desmita, 2009:211).

Siswa-siswi SMP masih berada dalam masa peralihan, namun sudah bersikap lebih dewasa. Hasil analisis data tentang perkembangan aspek psikologi, fisik, kognitif, sosial, dan spiritual siswa-siswi SMP, menunjukkan bahwa 11 (92 \%) responden menyatakan bahwa secara psikologi, para siswa-siswi SMP cenderung lebih dewasa dan terbuka. Siswa-siswi SMP sudah bisa memprioritaskan sesuatu yang lebih penting bagi dirinya sendiri seperti belajar dan membantu orang tua dari pada hanya bermain-main. Remaja sudah sampai pada tahap Unifying philosophy of life (memiliki falsafah hidup tertentu). Yaitu tahap munculnya kesadaran akan tujuan hidup dalam diri remaja. Artinya seseorang mulai mampu menempatkan dirinya di tengah-tengah kehidupan sebagai individu maupun dalam kelompok masyarakat.

Analisis data penelitian menunjukkan bahwa 8 (67 \%) responden menyatakan bahwa dari segi perkembangan fisik, para siswa-siswi SMP mengalami perubahan penampilan. Perubahan penampilan sangat terlihat karena masa remaja adalah masa di mana seseorang mengalami masa pubertas. Salah satu indikasi pertubuhan fisik seorang remaja adalah terjadinya perubahan bentuk tubuh atau fisik. Sebagai contoh, mulai tumbuhnya kumis dan janggut, jakun; bahu dan dada melebar; suara berat; tumbuh bulu di ketiak, di dada, di kaki, dan di lengan, dan di sekitar kemaluan; dan otot-otot menjadi kuat pada remaja lakilaki. Sedang pada perempuan terlihat dari membesarnya payudara dan pinggul, suara menjadi halus, tumbuh bulu di ketiak dan di sekitar kemaluan. Perubahan bentuk tubuh inilah yang akhirnya mempengaruhi perubahan penampilan remaja (bdk. Desmita, 2012:75-79).

Hasil analisa data penelitian juga mengungkapkan bahwa 7 (58 \%) responden menyatakan bahwa dari aspek sosial siswa-siswi SMP sudah mulai lebih banyak membangun relasi sosial dan mudah bergaul dengan teman sebaya. Dalam dunia remaja, hubungan dengan teman sebaya merupakan sesuatu yang sangat penting dan sangat berpengaruh pada perkembangan sosial remaja. Dalam hubungan ini, remaja juga belajar tentang hubungan timbal balik yang simetris. Artinya hubungan sosial didasarkan pada sikap saling memberi dan menerima secara adil (bdk. Desmita, 2009:220).

Hasil analisis data juga menunjukkan 8 (67 \%) responden menyatakan bahwa dari aspek spiritual, siswa-siswi SMP sudah bisa memusatkan diri pada Tuhan. Dalam masa remaja, seorang individu sudah mulai mampu mendalami ajaran-ajaran agama yang dia terima dari lembaga keagamaan yang resmi. Remaja juga sudah mampu berpikir kritis tentang ajaran keagamaan yang diterimanya. Di sisi lain, remaja juga sudah mulai mampu menemukan pengalaman bersatu 
dengan Tuhan melalui simbol-simbol dalam upacara keagamaan (bdk. Desmita, 2012:280).

Hasil analisis data mengungkapkan bahwa 7 (58 \%) responden menyatakan bahwa dari aspek kognitif, cara berfikir siswa-siswi SMP sudah lebih berkembang. Perkembangan kognitif remaja dapat dilihat dari cara berfikir remaja yang logis dan mampu mengambil kesimpulan atau membuat hipotesis dari sebuah informasi. Cara berfikir yang demikian ini memungkinkan remaja untuk berfikir secara sistematik. Artinya bahwa remaja sudah mampu berfikir secara terstruktur. Cara berfikir remaja seperti ini dapat membantu remaja untuk memecahkan masalah dengan terstruktur. Selain itu, cara berfikir ini juga membuat remaja bisa berfikir tentang kemungkinan-kemungkinan yang akan terjadi di masa yang akan datang. Dengan demikian remaja juga sudah mulai mampu merencanakan segala sesuatu yang harus dilakukannnya dan mempersiapkan diri untuk menerima kemungkinan-kemungkinan yang akan terjadi (bdk. Desmita 2012:107-108).

\subsection{Pemahaman tentang Materi Pengajaran Agama Katolik bagi Siswa- siswi SMP}

Tujuan pendidikan agama ialah untuk membentuk siswa menjadi pribadi yang beriman dan bertaqwa kepada Tuhan Yang maha Esa dan berakhlak mulia, dan demi peningkatan potensi spiritual (Komkat KWI, 2007:9). Untuk mewujudkan tujuan tersebut, maka materi Pendidikan Agama Katolik mencakup empat tema pokok, yaitu: pribadi siswa, Yesus Kristus, Gereja, dan Kemasyarakatan.

Topik-topik di bagian pertama pelajaran Agama Katolik memiliki fokus pada upaya membantu siswa untuk mengenal dirinya sebagai pribadi ciptaan Allah, baik sebagai laki-laki maupun sebagai perempuan. Siswa dibantu untuk menemukan kesadaran dan kepercayaan dirinya sebagai pribadi yang memiliki kelebihan sekaligus keterbatasan. Harapannya adalah supaya siswa mampu menerima diri apa adanya, mensyukuri, sekaligus mengarahkan dirinya untuk perkembangan yang lebih baik (Komkat KWI, 2004:14 (Buku Guru 1)). Hal ini tampak dari hasil analisa data penelitian tentang pengaruh Pendidikan Agama Katolik di sekolah dalam membantu para responden untuk lebih mengenal keunikan diri sendiri dan peranannya di tengah Gereja, menunjukkan bahwa 6 (50 \%) responden menyatakan bahwa Pelajaran Agama sangat membantu untuk mengenal diri mereka secara pribadi.

Salah satu kebutuhan remaja dalam mengembangkan dirinya adalah seorang pribadi yang dapat menjadi figur, model, sekaligus teladan hidupnya. Pendidikan Agama Katolik mengarahakan para siswa untuk menjadikan Yesus Kristus sebagai model dan teladan hidup yang sempurna bagi para siswa. Oleh 
karena itu, Pendidikan Agama Katolik mengajak para siswa mendalami hidup, karya, dan kepribadian Yesus untuk dijadikan model sekaligus arah pengembangan diri para siswa (bdk. Komkat KWI, 2004:155 (Buku Guru 1)). Hal senada juga tampak dari Analisa data penelitian tentang sejauh mana Pendidikan Agama Katolik di sekolah membantu siswa-siswi SMP lebih mengenal Yesus dan pewartaan-Nya, menunjukkan bahwa 11 (92 \%) responden menyatakan bahwa Pendidikan Agama Katolik di sekolah membantu mereka (siswa-siswi SMP) lebih mengenal Yesus dan pewartaan-Nya. Selain itu, para siswa juga diajak untuk mendalami karya-karya Yesus Kristus. Karya Yesus berpuncak pada peristiwa sengsara, wafat dan kebangkitan Yesus Kristus. Semua yang dialami Yesus menunjukkan jati diri Yesus yang sebenarnya. Keagungan jati diri Yesus tampak pula dalam keinginan-Nya membangun kelompok, kebersamaan, dan persekutuan. Yesus mengajak untuk terlibat dalam karya pewartaan Kerajaan Allah, menjalankan perutusan Bapa (bdk. Komkat KWI, 2004:13 (Buku Guru 2))

\subsection{Pemahaman tentang Proses Pengajaran Agama Katolik bagi Siswa- siswi SMP}

Kata pengantar Buku Guru mata pelajaran Pendidikan Agama Katolik dan Budi Pekerti (2017:3), mengaskan bahwa tujuan utama Pendidikan Agama Katolik ialah membangun kompetensi anak didik sebagai pribadi beriman, memekarkan dan menumbuhkembangkan anak-anak menjadi pribadi kristiani yang berlandaskan pada iman akan Yesus Kristus. Supaya dapat bersikap atas dasar iman kepada Yesus Kristus, maka perlu juga mengenal siapa itu Yesus. Karena itu, proses pembelajaran yang dilakukan juga harus memberikan pemahaman kepada anak-anak tentang pribadi Yesus. Sejalan dengan pernyataan di atas, hasil analisa data penelitian tentang tujuan utama kegiatan pendidikan dan pengajaran Pendidikan Agama Katolik di sekolah bagisiswa-siswi SMP, menunjukkan bahwa 5 (40 \%) responden menyatakan bahwa tujuan utama belajar pelajaran Agama Katolik di sekolah adalah untuk menguatkan iman. Selain itu, 4 (33 \%) responden menyatakan bahwa tujuan belajar Agama Katolik di sekolah yaitu untuk mengenal pribadi Yesus. Maka, dapat disimpulkan bahwa tujuan utama belajar Pendidikan Agama Katolik dan Budi Pekerti yaitu untuk menguatkan iman akan Yesus Kristus dengan lebih mengenal pribadi serta karya yang dilakukan-Nya.

Analisa data penelitian lapangan tentang bagaimana guru mengajarkanPendidikan Agama Katolik di sekolah bagisiswa-siswi SMP mengungkapkan bahwa, 4 (33 \%) responden menyatakan bahwa guru mengajar Pendidikan Agama Katolik berdasarkan isi Kitab Suci, dan buku pelajaran Agama Katolik. Setiap responden memiliki pengalaman dan pemahaman masing-masing tentang bagaimana guru mengajar. Selain materi, gaya mengajar guru juga 
mempengaruhi pencapaian tujuan Pendidikan Agama Katolik. Hasil analisa data penelitian lapangan tentang metode apa saja yang digunakan guru untuk menyampaikan materi Pedidikan Agama Katolik kepada siswa-siswi SMP, menunjukkan bahwa 4 (33 \%) responden menyatakan bahwa guru biasanya mengajar dengan menggunakan metode pengajaran secara lisan. Dengan kata lain, gaya mengajar guru dengan cara lisan masih ada sampai sekarang. Gaya mengajar ini lebih efektif untuk menyampaikan informasi dan pengertian kepada para siswa. Namun demikian, hal ini membuat siswa menjadi pasif. Gaya mengajar ini tidak salah, tetapi sudah tidak sepenuhnya relevan lagi jika melihat perkembangan zaman. Jika mau menyesuaikan dengan perkembangan zaman, gaya mengajar yang lebih relevan adalah gaya mengajar dengan menggunakan teknologi/media. Siswa diajak untuk berdialog dan berdiskusi menanggapi media yang ada. Dengan demikian, siswa mendapatkan kesempatan untuk berfikir, berdiskusi dan berpendapat menanggapi materi yang disampaikan. Cara ini akan memberikan pengalaman dan hasil belajar yang lebih baik bagi siswa karena sesuai dengan kebutuhan serta kemampuan siswa itu sendiri.

Dalam dunia modern seperti saat ini, gaya dan metode-metode pembelajaran yang digunakan oleh guru ini hendaknya selalu dikembangkan atau dimodifikasi sesuai dengan perkembangan zaman. Penggunaan media audio visual akan jauh lebih menarik dibandingkan dengan hanya sekedar ceramah dan menulis di papan tulis. Pemilihan metode mengajar yang tepat sesuai dengan situasi dan kondisi siswa akan sangat membantu siswa dalam memahami materi ajar yang disampaikan.

\subsection{Pemahaman tentang Pengaruh Pengajaran Agama Katolik Terhadap Perkembangan dan Penghayatan Iman Siswa-siswi SMP}

Tujuan umum pendidikan Agama katolik ialah untuk membangun kompetensi anak didik sebagai pribadi beriman, memekarkan dan menumbuhkembangkan anak-anak menjadi pribadi yang berlandaskan pada iman akan Yesus Kristus. sejalan dengan tujuan di atas, hasil analisa data lapangan tentang pengaruh pengajaran Agama Katolik di sekolah terhadap perkembangan iman siswa-siswi SMP, juga menunjukkan bahwa 8 (67 \%) responden menyatakan bahwa pengajaran Agama Katolik membuat imannya semakin berkembang menjadi lebih baik. Muara dari proses pembelajaran itu adalah menciptakan "habitus" dalam diri anak sehingga anak-anak mampu menjalankan perutusan-Nya dalam konteks kehidupannya dan kemampuannya masing-masing. pengajaran Agama Katolik di sekolah membuka hati responden untuk mewujudkan imannya dalam tindakan nyata. Hal ini merupakan "perwujudan kedewasaan iman serta keberanian memperjuangkan nilai-nilai luhur atas dasar 
kebenaran dan keadilan dalam konteks kehidupan konkret” (Komkat KWI, 2017:3).

Sebagai bentuk perwujudan ataupun hasil dari pembelajaran yang dilakukan, siswa memiliki kedewasaan iman yang terwujud dalam "habistus" hidup siswa. Habistus diperoleh siswa dari sekolah dan keluarga lewat pembiasaan. Analisa data penelitian tentang pengaruh pengajaran Agama Katolik di sekolah terhadap perkembangan penghayatan iman siswa-siswi SMP di sekolah, keluarga dan masyarakat, juga menunjukkan bahwa 6 (50 \%) responden menyatakan bahwa ketika di sekolah ia bisa lebih aktif mengikuti kegiatankegiatan rohani yang diselenggarakan sekolah.Habitus ini bukan hanya yang terjadi di dalam lingkungan sekolah saja, tetapi juga dalam lingkungan keluarga. Misalnya siswa aktif menjalankan kegiatan rohani bersama keluarganya, atau berani berinisiatif untuk mengajak keluarganya ke Gereja. Dengan kegiatan bersama keluarga ini siswa akan merasa bahwa hubungan keluarganya menjadi lebih dekat. Hal itu juga akan mendorong siswa untuk bersikap semakin lebih baik, misalnya menjadi lebih penurut, tidak bandel. Dari situasi kekeluargaan yang akrap, siswa juga akan belajar untuk semakin menghormati keluarganya yang sedang menjalankan kegiatan rohani (berdoa). Walaupun dalam situasi tertentu akan jarang terjadi kegiatan berdoa bersama keluarga karena kesibukan masing-masing.

Dalam hidup bermasyarakat, siswa juga akan mampu menghargai keberagaman di dalam masyarakat. Siswa juga akan memiliki dorongan untuk semakin aktif di tengah masyarakat. Bentuk keaktifan itu antara lain doa lingkungan, berani tampil dan menyampaikan pendapat di tengah masyarakat sekitarnya. Walaupun demikian, masih ada siswa yang belum bisa membaur dengan keberagaman yang ada di sekitarnya.

\section{KESIMPULAN}

Siswa-siswi SMP ialah para remaja yang telah tamat dari jenjang pendidikan SD dan melanjutkannya ke jenjang pendidikan menengah pertama. Mereka termasuk dalam kategori remaja berusia antara 13-15 tahun. Secara psikologis, siswa-siswi SMP mulai berperilaku lebih dewasa dan terbuka; sedang mengalami perkembangan fisik, kognitif, sosial, spiritual dan perubahan penampilan yang kelihatan lebih dewasa.

Secara umum, cara mengajar guru hendaknya disesuaikan dengan perkembangan zaman, misalnya dengan menggunakan teknologi/media. Dalam dunia modern seperti saat ini para responden mengungkapkan agar guru menggunakan media audio visual. Karena hal ini akan membantu proses mengajar lebih hidup dan menarik daripada cara mengajar dengan cara ceramah. Setiap siswa memiliki pengalaman rohani yang berbeda-beda berkaitan dengan proses 
pembelajaran Pendidikan Agama Katolik yang mereka terima. Pembelajaran Agama Katolik berpengaruh terhadap perkembangan iman dan perubahan perilaku para siswa-siswi. Mereka menjadi lebih rajin dan aktif dalam kehidupan atau kegiatan rohani di dalam Gereja. Selain itu para siswa juga terdorong untuk terlibat di dalam kehidupan bermasyarakat, serta bersikap lebih dewasa.

\section{DAFTAR PUSTAKA}

1993. Dokumen Konsili Vatikan II (R. Hardawiryana, penerjemah). Jakarta: Departemen Dokumen dan Penerangan KWI 2006. Kitab Hukum Kanonik (Codex Iuris Canonici). Jakarta: KWI

Budiningsih, C. Asri. 2005. Belajar dan Pembelajaran. Jakarta: PT Rineka Cipta. Depdiknas. 2008. Kamus Besar Bahasa Indonesia (Edisi ke-4). Jakarta: PT Gramedia Pustaka Utama.

Desmita, 2012. Psikologi Perkembangan Peserta Didik. Bandung: PT Remaja Rosdakarya.

Komkat KWI. 2007. Silabus Pendidikan Agama Katolik untuk Sekolah Menengah Pertama. Yogyakarta: Kanisius.

Komkat KWI. 2004. Persekutuan Murid-Murid Yesus - Pendidikan Agama Katolik untuk SMP (Buku Guru 1). Yogyakarta: Kanisius.

Komkat KWI. 2004. Persekutuan Murid-Murid Yesus - Pendidikan Agama Katolik untuk SMP (Buku Guru 2). Yogyakarta: Kanisius.

Komkat KWI.2017.Pendidikan Agama Katolik dan Budi Pekerti - Belajar Mengikuti Yesus (Buku Guru).Yogyakarta: Kanisius.

Supriyadi, Agustinus. 2012. Jurnal Pendidikan Agama Katolik Vol. 7, Tahun ke-4 - Remaja Katolik, Gereja, dan Ekaristi. Madiun: Lembaga Penelitian, STKIP Widya Yuwana.

Syah, Muhibbin. 2010. Psikologi Pendidikan Dengan Pendekatan Baru. Bandung: PT Remaja Rosdakarya.

Tse, Antonius. 2011. Jurnal Pendidikan Agama Katolik Vol. 6, tahun ke-3 Menata Masa Depan Gereja dan Bangsa melalui Pendidikan Iman Remaja (Katekese Remaja). Madiun: Lembaga Penelitian, STKIP Widya Yuwana. 